\title{
Large Scale Web Accessibility Evaluation - A European Perspective
}

\author{
Mikael Snaprud and Agata Sawicka \\ Faculty of Engineering, Agder University College, NO-4876, Norway \\ \{Mikael.Snaprud, Agata. Sawicka\} @hia.no
}

\begin{abstract}
The 2002 eEurope Action Plan advocated adoption of the WAI Content Guidelines in public EU web sites. Many of the European countries have performed web accessibility evaluations. Most of the evaluations are based on the Web Content Accessibility Guidelines from W3C/WAI. Still, a range of different evaluation methodologies and scoring schemes are deployed across the member states. This makes it hard to compare the web accessibility status between the different EU countries. The European Accessibility Internet Observatory aims to addresses this problem. The Observatory will produce automated, large scale web accessibility measurements based on which a range of monthly benchmarks will be produced and published online. In this way, the benchmarks should provide a useful input to the eAccessibility and eInclusion policy making.
\end{abstract}

Keywords: web accessibility, benchmarking, large scale evaluation, eInclusion, policy development.

\section{Introduction}

In the recent Riga declaration, ${ }^{1}$ the EU Member States and the European Commission have confirmed their commitment to ensuring accessibility of all public web sites by 2010. The Web Content Accessibility Guidelines from W3C/WAI indicate the desired accessibility standards. ${ }^{2}$ Most of the European countries have now implemented explicit policies on eAccessibility. Many also conduct evaluations based on the W3C/WAI Web Content Accessibility Guidelines. Still, a range of different evaluation methodologies and scoring schemes are deployed across the member states. This makes it hard to compare the web accessibility status between the different EU countries. Moreover, most evaluations involve manual assessments, hindering frequent assessments and decreasing comparability of the results. A uniform, large scale evaluation/benchmarking apparatus is needed to support a coherent evaluation of progress across EU with regard to the WCAG-compliance of the public web resources. A prototype of such apparatus was developed under the EU's Sixth Framework Programme by the European Internet Accessibility Observatory (EIAO) [1] [2].

${ }^{1} \mathrm{http} / / /$ ec.europa.eu/information_society/events/ict_riga_2006/doc/declaration_riga.pdf

2 http://www.w3.org/TR/WAI-WEBCONTENT/ 
The paper is organized as follows: First, a brief review of the current eAccessibility benchmarking practices in Europe is presented and discussed. Next, the European Accessibility Internet Observatory is described, focusing on the mechanisms developed to support flexible data presentation. Concluding remarks are provided in the final section.

\section{Accessibility Benchmarking Across Europe}

In accordance with the 2002 eEurope Action Plan, most of the European countries have now a national strategy/policy advocating conformance with W3C WAI/WCAG. Several countries have also introduced their own guidelines or even laws in the area of eAccessibility. See Table 1 for some examples.

Table 1. Overview of accessibility guidelines/ laws in a selection of countries. The URL indicates where the guidelines or the law is described on the web as accessed 2007-02-15.

\begin{tabular}{|c|c|c|}
\hline Country & Guidelines/law & URL \\
\hline Denmark & Guidelines for Internet publishing & $\begin{array}{l}\text { http://www.netsteder.dk/publ/1 } \\
\text { ndex.html }\end{array}$ \\
\hline Finland & $\begin{array}{l}\text { JHS } 129 \text { Guidelines for designing web } \\
\text { services in the public administration }\end{array}$ & $\begin{array}{l}\text { http://www.jhs- } \\
\text { suositukset.fi/suomi/jhs129 }\end{array}$ \\
\hline France & $\begin{array}{l}\text { Circulaire du } 7 \text { octobre } 1999 \text { relative aux } \\
\text { sites internet des services et des } \\
\text { établissements publics de l'Etat }\end{array}$ & $\begin{array}{l}\text { http://www.admi.net/jo/19991 } \\
\text { 012/PRMX9903708C.html }\end{array}$ \\
\hline Germany & $\begin{array}{l}\text { Barrierefreie Informationstechnik } \\
\text { Verordnung }\end{array}$ & $\begin{array}{l}\text { http://bundesrecht.juris.de/bitv } \\
\text { /index.html }\end{array}$ \\
\hline $\begin{array}{l}\text { The } \\
\text { Netherlands }\end{array}$ & $\begin{array}{l}\text { Guidelines for accessibility and } \\
\text { sustainability of government web sites }\end{array}$ & $\begin{array}{l}\text { http://webrichtlijnen.overheid. } \\
\mathrm{nl} /\end{array}$ \\
\hline Ireland & The Irish Guidelines for Web Accessibility & $\begin{array}{l}\text { http://accessit.nda.ie/guideline } \\
\text { index_1.html }\end{array}$ \\
\hline Norway & $\begin{array}{l}\text { Quality criteria covering accessibility, } \\
\text { usability and usefulness. The guidelines is a } \\
\text { Norwegian translation of WCAG/WAI }\end{array}$ & $\begin{array}{l}\text { http://www.norge.no/kvalitet/ } \\
\text { kvalitet2006/kriterier.asp }\end{array}$ \\
\hline Sweden & Vägledning 24-timmars webben 2.0 & $\begin{array}{l}\text { http://www.verva.se/web/t/Pa } \\
\text { ge__ 1154.aspx }\end{array}$ \\
\hline UK & $\begin{array}{l}\text { The Guidelines for UK government } \\
\text { websites. } \\
\text { Those guidelines are also supplemented by a } \\
\text { guide for public procurement, Guide to good } \\
\text { practice in commissioning accessible } \\
\text { websites, PAS 78:2006 }\end{array}$ & $\begin{array}{l}\text { www.drc-gb.org/pas } \\
\text { http://www.cabinetoffice.gov. } \\
\text { uk/e- } \\
\text { government/resources/handbo } \\
\text { ok/html/htmlindex.asp }\end{array}$ \\
\hline
\end{tabular}

A collection of links to accessibility guidelines on government web sites is available from the site Standards Schmandards. ${ }^{3}$ A list of policies related to web accessibility is maintained by $\mathrm{W} 3 \mathrm{C}$. $^{4}$

\footnotetext{
${ }^{3}$ http://www.standards-schmandards.com/projects/government-guidelines/

${ }^{4}$ http://www.w3.org/WAI/Policy/
} 
To yield tangible results, the policy initiatives and the guidelines should be followed by systematic measurement and monitoring activities. It would also be advantageous if the national progress was measured in such a way as to allow for international comparisons. One of the first comprehensive pan-European eAccessibility assessments was the Top of the Web survey carried out in November 2003.

The 2003 survey has been followed in 2005 with the UK Cabinet Office eAccessibility survey. The assessment was conducted for 436 web sites and covered 43 WCAG checkpoints. 13 WCAG checkpoints were evaluated using automated tools; others were assessed manually. The results were presented using custom percentage scale, with no possibility of acquiring detailed information regarding the scores of particular countries/web sites on specific WCAG checkpoints. The report was published in a PDF document available online. As such, it prohibited custom data drills and sorting.

While providing a useful European overview of the eAccessibility status, the 2005 survey has not yet been followed by similar pan-European assessments. There are several eGovernment surveys carried out on an annual basis.

The eGovernment readiness report from the United Nations ${ }^{5}$ covers the "official" national web sites and a selection of ministry level web sites for each country. The 2005 survey included a WCAG level 1 conformance check by using the using the online tool from Watchfire. ${ }^{6}$ A list of the counties conforming is presented in the report. The series of Web Based Survey on Electronic Public Services Reports prepared by Cap Gemini for the European Commission has in the 6th ${ }^{7}$ and most recent measurement report included accessibility for assessment, although not in the final score. These reports does however not yet include detailed quantifiable information the development accessibility over time.

While there seems to be no continuous pan-European eAccessibility measurement and monitoring initiative, there is a range of interesting initiatives at national level. Some of the most advanced eAccessibility evaluation activities on national level are today carried out by Denmark, Netherlands, Norway and Sweden. On the panEuropean level, there has recently been one evaluation effort undertaken, during the UK Presidency. Table 2 provides an overview of 5 national benchmarking initiatives.

In all cases, the measurements are performed by public agencies. Most of the evaluation schemes are quite recent, with only the Danish Best on Web and Norwegian Norge.no dating back to 2000 and 2001, respectively. The benchmarks are typically published on a yearly basis, with an opportunity to view past results. The exceptions are the Swedish benchmark that is issued quarterly and the Dutch Overheid.nl Monitor that evaluate at least once a year, and in addition on demand as required by the web site owner or the team responsible for the Monitor.

\footnotetext{
${ }^{5}$ http://unpan1.un.org/intradoc/groups/public/documents/un/unpan021888.pdf

${ }^{6}$ http://webxact.watchfire.com/

7 http://ec.europa.eu/information_society/eeurope/i2010/docs/benchmarking/ online_availability_2006.pdf
} 
Table 2. Comparative review of 5 national eAccessbility benchmarking initiatives

\begin{tabular}{|c|c|c|c|c|c|}
\hline & $\mathrm{DK}^{8}$ & $\mathrm{DK}^{9}$ & $\mathrm{NL}^{10}$ & $\mathrm{NO}^{11}$ & $\mathrm{SE}^{12}$ \\
\hline \multicolumn{6}{|c|}{ General information } \\
\hline $\begin{array}{l}\text { Responsible } \\
\text { agency }\end{array}$ & public & public & public & public & public \\
\hline $\begin{array}{l}\text { First } \\
\text { evaluation }\end{array}$ & 2006 & 2000 & 2005 & 2001 & 2005 \\
\hline Frequency & $?$ & yearly & yearly & yearly & quarterly \\
\hline $\begin{array}{l}\text { Past results } \\
\text { availability }\end{array}$ & yes & $\begin{array}{l}\text { yes, from } \\
2001\end{array}$ & yes & $\begin{array}{l}\text { yes, apart } \\
\text { from } 2002\end{array}$ & yes \\
\hline Languages & Danish & Danish & Dutch & Norwegian & Swedish \\
\hline \multicolumn{6}{|c|}{ Evaluation scope } \\
\hline URLs, 2006 & 122 & 800 & 524 & 691 & 1000 \\
\hline $\begin{array}{l}\text { Evaluation } \\
\text { areas }\end{array}$ & accessibility & $\begin{array}{l}\text { usability, digital } \\
\text { self-service, } \\
\text { openness, } \\
\text { technical } \\
\text { accessibility }\end{array}$ & accessibility & $\begin{array}{c}\text { usability, } \\
\text { usefulness, } \\
\text { accessibility }\end{array}$ & $\begin{array}{l}\text { accessibility } \\
\text { Dublin Core }\end{array}$ \\
\hline $\begin{array}{l}\text { Accessibility } \\
\text { criteria }\end{array}$ & $\begin{array}{c}45 \text { WCAG } \\
8 \text { national } \\
\text { guidelines }^{13}\end{array}$ & $12 \mathrm{WCAG}$ & 14 WCAG & $10 \mathrm{WCAG}$ & $\begin{array}{c}10 \text { WCAG + } \\
\text { Custom }\end{array}$ \\
\hline $\begin{array}{l}\text { Evaluation } \\
\text { method }\end{array}$ & $\begin{array}{c}\text { semi- } \\
\text { automated }\end{array}$ & $\begin{array}{c}\text { semi- } \\
\text { automated }^{14}\end{array}$ & $\begin{array}{l}\text { automated } \\
+ \text { manual }\end{array}$ & $\begin{array}{l}\text { semi- } \\
\text { automated }\end{array}$ & automated \\
\hline \multicolumn{6}{|c|}{ Data presentation } \\
\hline $\begin{array}{l}\text { Publishing } \\
\text { outlet }\end{array}$ & $\begin{array}{c}\text { online open } \\
\text { office } \\
\text { documents }\end{array}$ & web & web & web & $\begin{array}{c}\text { web / } \\
\text { spreadsheet }\end{array}$ \\
\hline $\begin{array}{l}\text { Dynamic } \\
\text { sorting }\end{array}$ & no & yes & no & yes & $\begin{array}{c}\text { yes } \\
\text { (spreadsheet) }\end{array}$ \\
\hline $\begin{array}{l}\text { Regional } \\
\text { aggregation }\end{array}$ & no & no & yes & no & no \\
\hline $\begin{array}{l}\text { Results } \\
\text { format }\end{array}$ & $\begin{array}{l}\text { number of } \\
\text { failed tests }\end{array}$ & $\begin{array}{l}\text { custom } \\
\text { percentage/ } \\
\text { point scales }\end{array}$ & $\begin{array}{l}\text { custom } \\
\text { percentage } \\
\text { scale }\end{array}$ & $\begin{array}{l}\text { custom } \\
\text { percentage } \\
\text { scale }\end{array}$ & $\begin{array}{c}\text { [yes/no] / No } \\
\text { of instances, } \\
\text { failed tests }\end{array}$ \\
\hline $\begin{array}{l}\text { Detailed } \\
\text { WCAG test } \\
\text { results }\end{array}$ & no & yes & no & no & partly \\
\hline
\end{tabular}

The number of URLs covered by the evaluations differs greatly from 122 web sites covered by the oio.dk Danish initiative, to about 1000 of web sites covered by the Swedish evaluation. With the exception of the Swedish initiative and the report issued

\footnotetext{
${ }^{8}$ Danish portal on public information, http://www.oio.dk/tilgaengelighed/ kortlaegning07

${ }^{9}$ Danish Top of the Web project, http://www.bedstpaanettet.dk

${ }^{10}$ Dutch portal to public information, http://webrichtlijnen.overheid.nl/

11 Gateway to the public sector in Norway, http://www.norway.no/

12 Verva-Swedish Administrative Development Agency, http://www.verva.se

13 The additional national guidelines concern the use of electronic forms and PDF documents.

14 The manual evaluations are carried out by two independent experts.
} 
by the UK Office Cabinet, all the evaluations cover also other areas beyond the accessibility. With respect to the accessibility assessment, all the evaluations draw on the W3C/WCAG checkpoints, although they differ in their coverage scope.

The evaluations are carried out in different ways, the Dutch and the Swedish initiatives are largely automated, whereas the others are based on semi-automated assessments involving manual expert evaluation supported by the results of the automated $\mathrm{W} 3 \mathrm{C}$ validators where appropriate. The UK Cabinet Office details which of the WCAG checkpoints are evaluated exclusively manually and which involve the automated checks. The results of the assessments are in all cases available online, supporting data drilling and sorting to varied degree. None of the reviewed tools supports aggregation across sectors. Only the Dutch monitoring tool supports a dynamic aggregation/disaggregation across regions; the other reports provide the eAccessibility status for individual web site or group of web sites belonging to one particular region. In most cases, a single eAccessibility measure is provided and expressed using a custom percentage scale. With an exception of the Danish Best on Web initiative, none of the reports supports disaggregation of the overall score to the level of the specific WCAG checkpoints tests.

The evaluation initiatives briefly outlined above, illustrate a range of interesting initiatives. The potential impact of the measurements could potentially increase if pan-European comparisons where supported.

A comparison of the initiatives show that the main elements of the methods used, from sampling, though guidelines and evaluation to the presentation of results are different among the counties. In particular, the evaluation, there are different variants of national guidelines based on WCAG. Also the schemes to assign an overall score for a web site can include additional aspects of the web site like usefulness or usability in Norway [1], and four additional aspects are included in the score in the Netherlands. To locate good practice and to encourage an element of competition towards a more inclusive Information Society, a unified web evaluation methodology is needed.

\section{The EIAO Approach}

The WAB (Web Accessibility Benchmarking) ${ }^{15}$ cluster is co-funded by the European Commission, and was organised to contribute to harmonisation of the efforts towards an inclusive information society in Europe. The main activity of the cluster is to define a unified web evaluation methodology (UWEM) for conformance to the WCAG1.0 guidelines and ensuring a smooth transition to the announced WCAG2.0 guidelines. The cluster initially consisted of the project EIAO ${ }^{16}$, Support-EAM and BenToWeb.

The European Internet Accessibility Observatory (EIAO, www.eiao.net) currently develops a prototype online Observatory to perform large scale automatic accessibility benchmarking based on the UWEM1.0, with a plan to evaluate and

\footnotetext{
15 http://www.wabcluster.org/

16 The project is co-funded by the European Commission DG Information Society and Media, under the contract IST-004526.
} 
present results from 10000 public European web sites monthly. The first results from the large scale evaluation is due for public release in June 2007. All the software developed for the Observatory is developed and released as Open Source [3][4] to encourage review, facilitate participatory design [5][6], and pave the way for further improvements. This design decision has proved particularly useful to invite new developers to the team and reuse the solutions provided by other projects.

The results from the prototype implementation indicate that adapting and integrating existing tools rather than building a system from scratch has been very suitable for the task. This choice has also, as implemented by the highly talented development team, resulted in an extensible architecture for large scale web accessibility evaluation [7][8].

\section{UWEM: 146 tests}

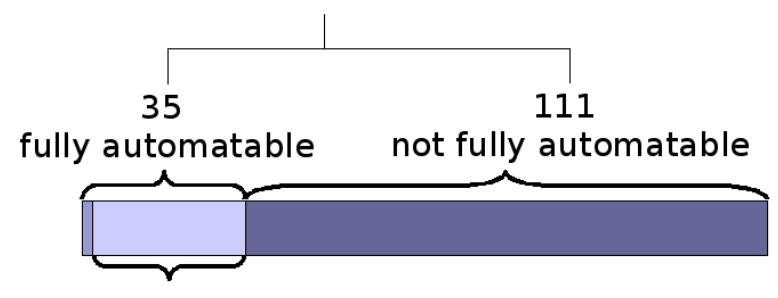

Fig. 1. Coverage of UWEM tests in the EIAO demonstrator

UWEM contains in total 146 tests. 35 of these tests can be fully automated (see Figure 1), and 31 of these are implemented by the EIAO WAMs (covering 19 WCAG checkpoints). In addition, results are included from 2 UWEM tests provided by the BenToWeb project. ${ }^{17}$

Only automated tests are viable to use for large scale testing. However, to cover all tests manual and labour intensive evaluation is needed. The large scale evaluation is expected to be useful to identify and disseminate good practice from a larger sample of web sites. A combination of both could be thus be used to cater for a low cost and frequent evaluation to be supplemented by more in depth manual evaluation of particularly interesting web sites.

\subsection{Presentation of the Collected Evaluation Results}

The reporting capacity of the Observatory is designed to allow for easy generation of benchmarking lists, as well as to support more advanced functionality for drilling down into details on a given web site. The reports have been designed primarily to support policy makers in their work [9] .They should be accessible through a flexible and yet intuitive user interface that facilitates analysis of the data in the data warehouse from different perspectives [10][11].

The most aggregated score shows the overall barrier probability for all the web sites covered in Europe. From this aggregated level the user can drill down through

${ }^{17} \mathrm{http}: / /$ bentoweb.org/ 
the county level, and further down to a county and even onwards to a given web site and the barriers detected on this particular web site. Figure 2 illustrates the drill-down and roll-up navigation of the reports. Please note that the data in the following figures are included for demonstration purposes only.

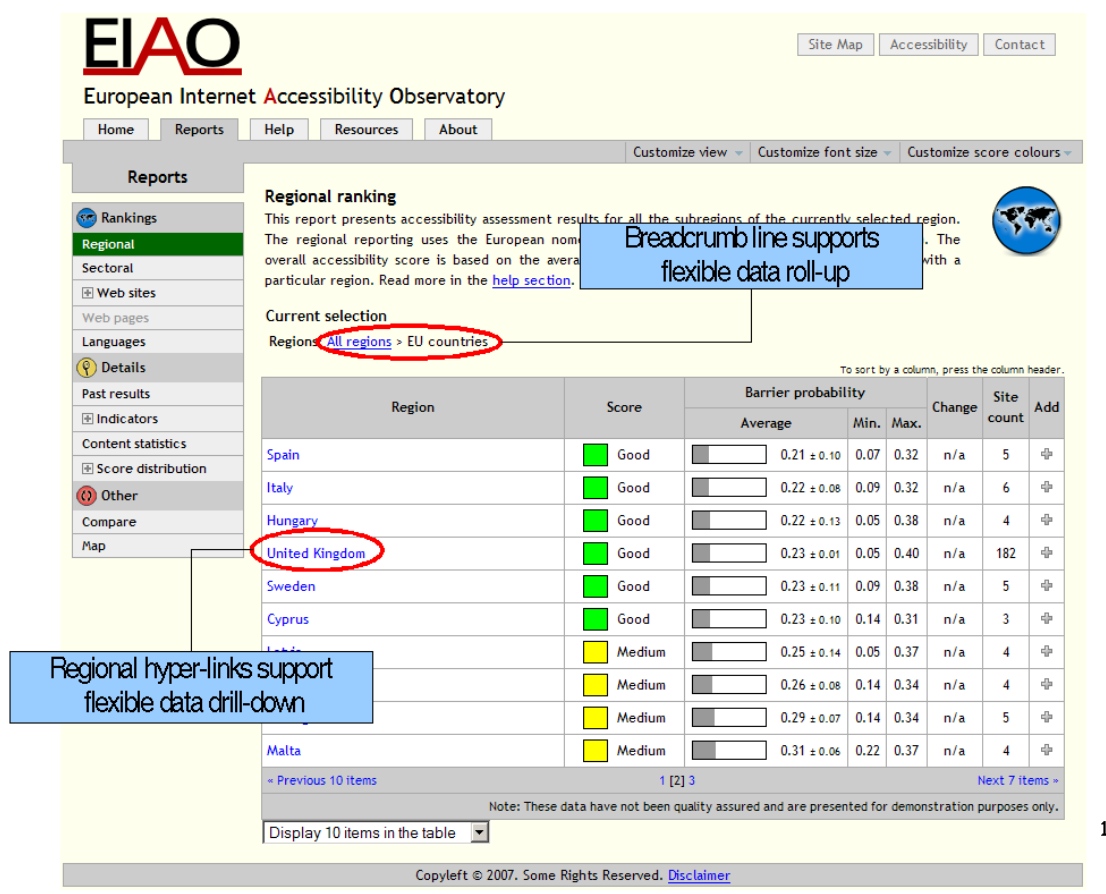

Fig. 2. The EIAO reports support drill-down and roll-up for navigation in the data warehouse. Please note that the data in the figure is included for demonstration purposes only

Aggregations can be performed also on other items like the detected barriers among on all the sites in Europe or in a given country, For each report the columns can be sorted as needed allowing for different perspectives of the data. see Figure 3 .

The barriers shown in Figure 3 are corresponding to the set of UWEM tests that can be automated according to UWEM 1.0. A similar view can be shown also for the barriers discovered for a given web site. Since a site is represented by a limited number of web pages from the evaluated web site, the detected barriers will only be a representative selection, not all barriers that could be detected automatically on all pages of the web site. The selection of web pages is carried out according to a random walk algorithm.

An other form of aggregations is illustrated in Figure 4, where the distribution of web sites among scores as defined in UWEM 1.0 is depicted. In addition figure 4 shows a geographical to give a further aggregated view of the results. 


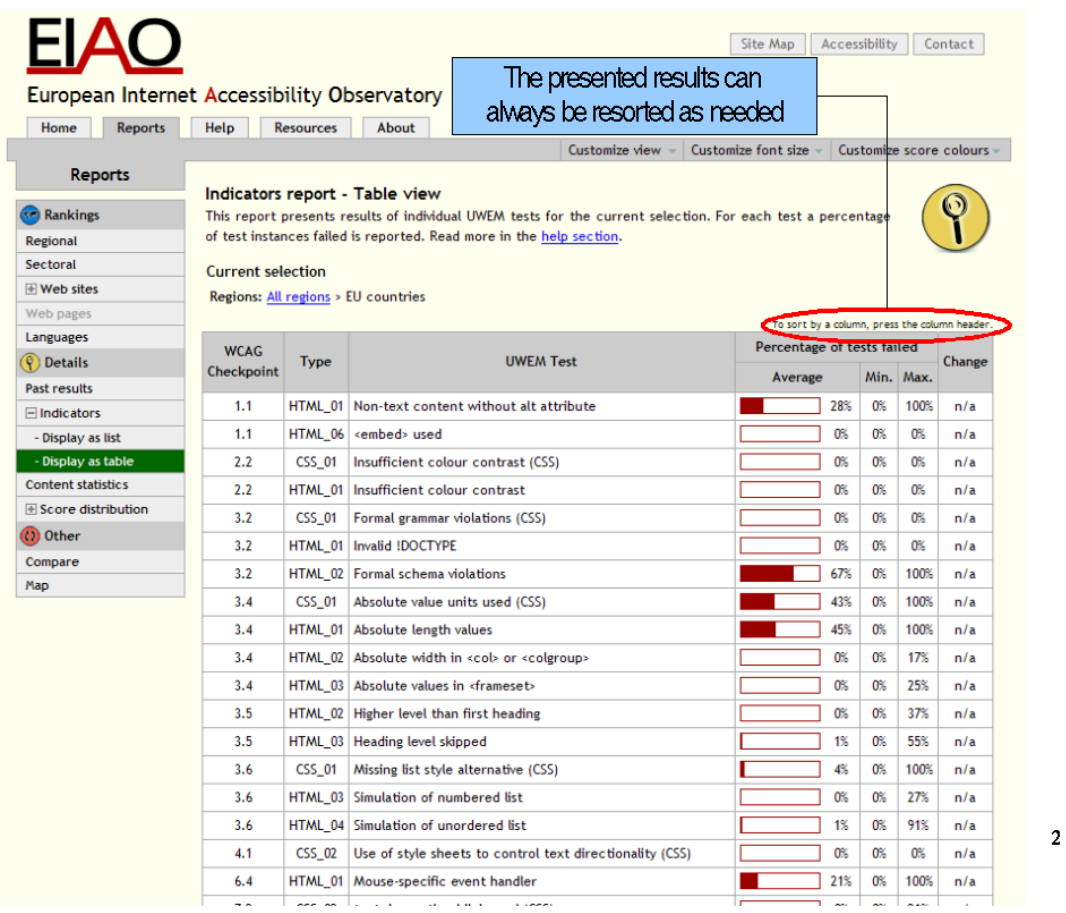

Fig. 3. Aggregation on detected barriers among all web sites evaluated across Europe. Please note that the data in the figure is included for demonstration purposes only.

In addition to the current status of the accessibility barriers on public web sites, the reports have been designed to show the development over time. In this way, policy makers may be able to monitor the longer term impact of the implemented policies.

The approach to visualise the data could also be used present other kinds of data. For example the accessibility evaluation could be extended with additional indicators to cover other aspects of eGovernment development such as update frequency of web content or to what extent citizens are requested to fill in the same information in different government forms.

\section{Concluding Remarks}

Several national benchmarking initiatives are already producing very interesting results and publish them on a regular basis. They are all based on WCAG1.0 and have several similar features. However, due to differences in sampling, in the interpretation of WCAG1.0, and in the representation of the evaluation results, the comparison of results among different measurements is hardly feasible.

Wide use of a common evaluation methodology, based on WCAG, would facilitate international comparisons and enhance the spread of good practice. 


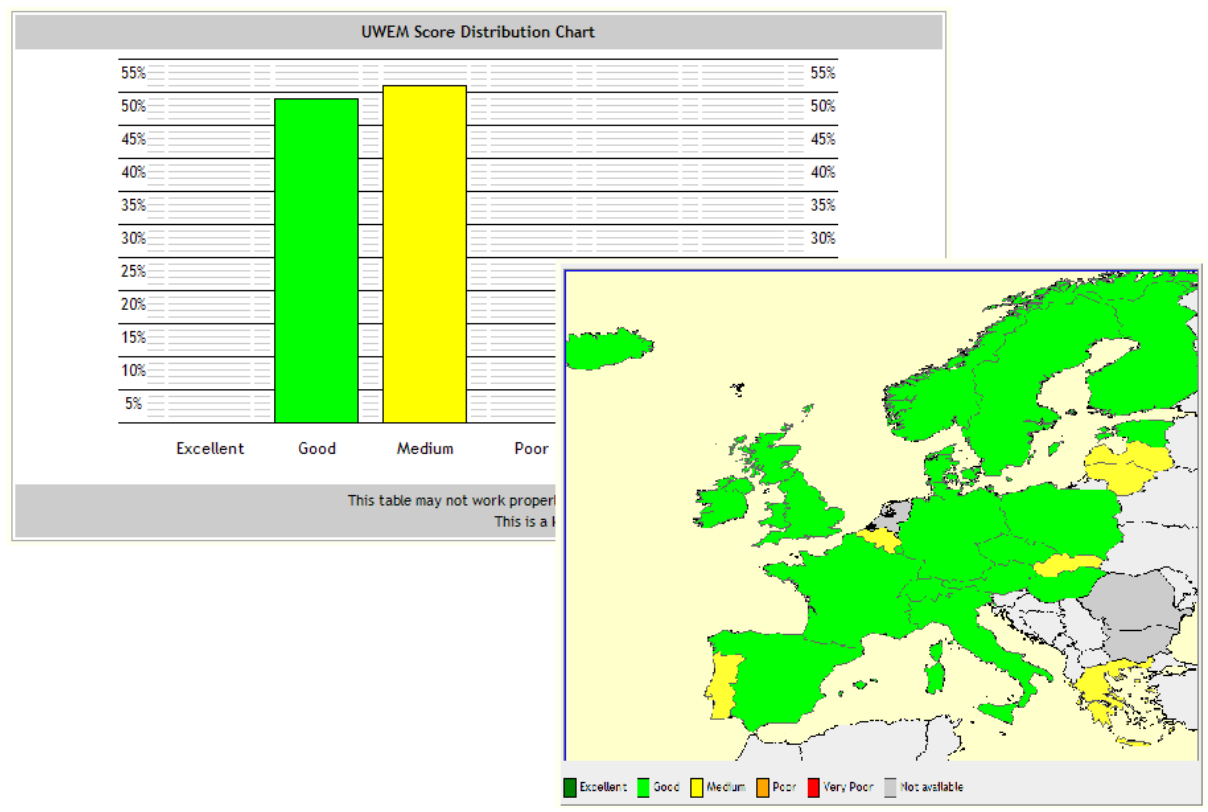

Fig. 4. Distribution of web sites among the barrier probability scores as defined in UWEM, shown as bar chart and as geographical map. Please note that the data in the figure is included for demonstration purposes only.

In this way, the unified web evaluation methodology (UWEM) based on WCAG from W3C, can fuel the development towards a more Inclusive European Information Society. A demonstrator for UWEM 1.0 has been implemented as an open source application by the EIAO project. The the first large scale evaluation results from 10.000 European public web sites are now available as online reports.

Acknowledgements. Please note that the results presented in this paper are built on the achievements of the open source community, and in is the result of a team effort with substantial contributions from 10 organisations. You find more details on the EIAO project team, the organisations, and their contributions on the project web site: http://www.eiao.net.

\section{References}

1. Aslaksen, F., Fardal, F., Snaprud, M.: The Role of Benchmarking in Concerted Actions to Increase Accessibility, 10th International Conference on Computers Helping People with Special Needs, ICCHP 2006, 12-14 July 2006, Linz. In: Miesenberger, K., Klaus, J., Zagler, W., Karshmer, A.I. (eds.) ICCHP 2006. LNCS, vol. 4061, pp. 258-262. Springer, Heidelberg (2006)

2. Craven, J., Snaprud, M.: Positive Steps to Assessing, Monitoring and Comparing the Accessibility of Public Websites: Introducing the European Internet Accessibility Observatory, FreePint (August 24, 2006) pp. 18-22 (2006) 
3. Perens, B.: The open source definition. In: DiBona, C., Ockman, S., Stone, M. (eds.) Open Sources: Voices from the Open Source Revolution. O'Reilly and Associates, Cambridge, Massachusetts (1999)

4. Duque, R., Collins, M., Abbate, J., Azambuja, C.C., Snaprud, M.: History of Information Technology. In: Shrum, W., Benson, K.R., Bijker, W.E., Brunnstein, K. (eds.) Past, Present and Future of Research in the Information Society, Springer, Heidelberg (2007)

5. Nygaard, K., Bergo, T.O.: Planlegging, styring og databehandling. Grunnbok for fagbevegelsen (Planning, management and data processing. Handbook for the labour movement) vol. I. Oslo: Tiden norsk forlag (1973)

6. Mohaghegi, P., Snaprud, M., Pillai, A., Ulltveit-Moe, N.: Including Users and External Contributors in an European Research Project, Digital Inclusion and Open Source October $20-21,2005$ Oslo, Norway (2005)

7. Snaprud, M.H., Ulltveit-Moe, N., Pillai, A.B., Olsen, M.G.: A Proposed Architecture for Large Scale Web Accessibility Assessment. In: Miesenberger, K., et al. (eds.) ICCHP 2006. LNCS, vol. 4061, pp. 234-241. Springer, Heidelberg (2006)

8. Snaprud, M.: Early results from automatic accessibility benchmarking of public European web sites from the European Internet Accessibility Observatory (EIAO). In: Proc. of Design for All, DFA, September 13-15 2006, Rovaniemi, Finland (2006)

9. Snaprud, M., Sawicka, A.: The European Internet Accessibility Observatory project, UNPAN, Expert Group Meeting on E-Participation and E-Government, Budapest, Hungary July 27-28 2006 proceedings yet (to appear) (2006) paper available at http://unpan1.un.org/intradoc/groups/public/documents/UN/UNPAN023676.pdf

10. Sawicka, A., Snaprud, M., Unander, E.H.: Online Presentation of Large Volume Web Accessibility Data Within EIAO. In: The second Workshop on Web Accessibility and Metamodelling (WWAM 2006) June 13-15 2006 Agder University College, Grimstad, Norway (2006)

11. Sawicka, A., Snaprud, M.: eAccessibility Data for eInclusion Policy Making: Reports from a Large Scale Internet Observatory. In: Proc. of Design for All, DFA, September $13-$ 15, 2006, Rovaniemi, Finland (2006) 